\title{
STUDI FENOMENOLOGI : PENGALAMAN PERAWAT TERKAIT KETIDAKBERHASILAN RESUSITASI PADA NEONATAL DENGAN ASFIKSIA DI RUANG NEONATUS RSUD DR. R. SOEDJONO SELONG LOMBOK TIMUR
}

\author{
Rita Rinjani $^{1}$, Retty Ratnawati ${ }^{2}$, Septi Dewi Rachmawati ${ }^{3}$ \\ ${ }^{1}$ Dinas Kesehatan Kabupaten Lombok Timur \\ ${ }^{2,3}$ Pengajar program Magister Keperawatan Fakultas Kedokteran Universitas Brawijaya
}

ABSTRAK

Asfiksia masih menempati urutan kedua sebagai penyebab kematian neonatal di RSUD Dr. R Soedjono Selong Lombok Timur. Ketidakberhasilan suatu tindakan resusitasi yang menyebabkan kematian neonatus melibatkan kondisi yang kompleks dan memberikan dampak secara psikologis yang merupakan stressor tersendiri bagi perawat. Penelitian ini bertujuan untuk mengeksplorasi pengalaman perawat terkait ketidakberhasilan resusitasi pada neonatal dengan asfiksia di ruang neonatus RSUD Dr. R. Soedjono Selong Lombok Timur. Desain penelitian yaitu kualitatif dengan pendekatan fenomenologi interpretif yang melibatkan 7 orang perawat ruang neonatus yang pernah mengalami ketidakberhasilan resusitasi pada neonatal asfiksia. Data dikumpulkan melalui wawancara mendalam dan dianalisis berdasarkan pendekatan analisa tematik Braun \& Clarke. Penelitian menghasilkan 8 tema yaitu memahami kondisi kegawatanpada neonatus yang membutuhkan tindakan resusitasi segera, melakukan resusitasi dengan kesadaran akan keterbatasan yang dimiliki, mengalami dilema dengan adanya kehadiran keluarga, merasakan ketidaktentraman hati karena kegagalan resusitasi, berupaya meringankan beban pikiran, mengembalikan semua permasalahan kepada Tuhan, menerima kegagalan sebagai bagian dari pembelajaran, dan menginginkan peningkatan kualitas pelayanan pada kegawatan neonatus. Dapat disimpulkan bahwa perawat memahami kondisi kegawatan pada neonatus dengan asfiksia dan melakukan tindakan resusitasi segera walaupun sadar akan keterbatasan kompetensi dan peralatan yang dimiliki serta hambatan yang timbul dari kehadiran keluarga pasien. Ketidakberhasilan resusitasi menyebabkan stressor dan mepengaruhi psikologis perawat. Strategi perawat untuk mengatasi permasalah tersebut dengan mekanisme koping yang konstruktif sehingga perawat dapat mengambil hikmah dibalik kegagalan. Dukungan dari manajemen terkait peningkatan sumber daya manusia, dan pemberian dukugan serta penyediaan fasilitas resusitasi yang memadai dibutuhkan guna mengurangi kejadian ketidakberhasilan resusitasi pada neonatal dengan asfiksia di masa yang akan datang.

Kata Kunci: Pengalaman perawat, ketidakberhasilan resusitasi neonatal, asfiksia

\begin{abstract}
Neonatal death due to asphyxia in Dr. R. Soejono General Hospital in Selong East Lombok in recent years is still quite high, where asphyxia still ranks second as a cause of neonatal mortality. Unsuccessful resuscitation which caused the death of a neonate is a complex process and present psychological impact which being a stressor for nurses. The aim of these study was to explore the nurse experience related to the unsuccessful resuscitation of asphyxiated neonate in neonatal department Dr. R. Soejono General Hospital in Selong East Lombok. The study used qualitative design with an interpretive phenomenological approach involving 7 neonatal department nurses who have related experience to unsuccessful resuscitation in the asphyxiated neonate. Data were collected through in-depth interviews and analyzed by thematic analysis Braun \& Clarke approach. This study resulted in 8 (six) themes, namely understanding the criticalness conditions in neonates which requiring immediate resuscitation, perform resuscitation with awareness of the limitations, a dilemma with the presence of the family, feel unpeaceful heart because of the unsuccessful resuscitation, attempt to ease the personal burden, return all the problems to God, accept failure as part of learning, and seeking the service quality improvement on the neonates criticalness. In conclusion nurses understand the asphyxiated neonates criticalness and perform immediate resuscitation although aware of the limitations of competence and facilities as well as the present obstacles from the presence of the patient's family. The unsuccessful resuscitation cause psychological stressor to the nurse. Nurse strategies to overcome these problems are with constructive coping mechanisms so that the nurse can take the wisdom behind the unsuccessfulness. The support of the management related to the development of human resources, and the provision of the support systems and the provision of adequate resuscitation facilities are needed in order to reduce the incidence of unsuccessful resuscitation in the asphyxiated neonatal in the future.
\end{abstract}

Keyword: Nurse experience, unsuccessful neonatal resuscitation, asphyxia

Jurnal Ilmu Keperawatan, Vol: 4, No. 2 ; Korespondensi : Rita Rinjani. Dinas Kesehatan Lombok Timur. Jl. A. Yani No. 100 Selong Lombok Timur Email : rita.rinjani69@gmail.com No. Hp: 081803693023 


\section{PENDAHULUAN}

Asfiksia neonatorum merupakan suatu keadaan dimana bayi tidak dapat segera bernafas secara spontan dan teratur setelah lahir (WHO, 2012). Kondisi asfiksia merupakan kombinasi kompleks antara hipoksemia, hiperkapnea dan insufisiensi sirkulasi yang disebabkan oleh berbagai macam faktor resiko (ACOG \& AAP, 2015). Apabila kondisi ini berlangsung lama, akan menyebabkan kerusakan permanen dari sistem saraf pusat atau organ vital lainnya sehingga dapat menyebabkan kegagalan sistem pernafasan yang dapat jatuh pada kondisi kegawatan sistem pernafasan dan kardiovaskular (Karloicz, et.al, 2011).

Kematian neonatal karena asfiksia di RSUD Dr. R. Soejono Selong Lombok Timur, pada beberapa tahun terakhir masih cukup tinggi, dimana asfiksia masih menempati urutan kedua sebagai penyebab kematian neonatal.

Hasil studi pendahuluan yang dilakukan peneliti pada bulan Januari 2016 pada beberapa orang perawat di ruang neonatus, didapatkan kenyataan bahwa mereka ratarata pernah memiliki pengalaman terkait ketidakberhasilan resusitasi pada neonatal dengan asfiksia. Ketidakberhasilan tersebut dimanifestasikan oleh perawat secara berbeda-beda, ada yang mengatakan bahwa saat tidak berhasil melakukan resusitasi ada perasaan frustasi, merasa bersalah, kecewa dan terkadang marah serta merasa tidak cukup kemampuan dalam melakukan tindakan tersebut. Secara umum mereka merasa bahwa ketidakberhasilan suatu tindakan resusitasi memberikan dampak secara psikologis yang merupakan stressor bagi perawat.

Kegagalan resusitasi yang menyebabkan kematian seorang anak setelah upaya resusitasi menghasilkan emosi dan perasaan yang kuat, apapun bentuk resusitasi dapat berpotensi menjadi stress emosional bagi perawat (Drotske \& De Viliers, 2007). Pengalaman kegagalan melakukan resusitasi dapat menimbulkan rasa frustasi yang mendasar, marah, perasaan bersalah, putus asa dan perasaan tidak professional (Cole, et.al, 2001).

Kesulitan mengelola stress adalah salah satu tema yang muncul dalam studinya yang mempengaruhi perawat dalam melakukan resusitasi( Cole, et al, 2001; Hemming, et.al, 2003).

Berdasarkan fenomena-fenomena di diatas, peneliti tertarik untuk melakukan penelitian dengan pendekatan kualitatif menggunakan studi fenomenologi dengan beberapa pertimbangan yaitu dengan menggunakan pendekatan kualitatif fenomenologi akan dapat memberikan pemahaman yang 
mendalam mengenai makna dari suatu pengalaman hidup atau fenomena dari beberapa individu melalui sudut pandang individu yang mengalaminya (Moleong, 2014; Taylor, Kemode, \& Robert, 2007).

Penelitian ini penting untuk dilakukan, mengingat potensi terjadinya kematian pada neonatal yang mengalami asfiksia masih cukup tinggi di RSUD Dr. R. Soedjono Selong Lombok Timur. Penelitian di bidang resusitasi terutama terkonsentrasi pada aspek medis dan biofisik. Pengalaman subjektif dari mereka yang melakukan resusitasi dan emosi perawat terkait ketidakberhasilan resusitasi serta penyebab ketidakberhasilan tersebut dari sudut pandang perawat jarang dibahas. Selain itu, penelitian dan literatur terkait yang mengeksplorasi secara lebih mendalam pengalaman perawat terkait ketidakberhasilan resusitasi pada neonatal asfiksia menggunakan pendekatan kualitatif belum banyak diteliti.

Penelitian sebelumnya telah dilakukan oleh Maesyaroh (2015) mengeksplorasi pelaksanaan resusitasi kegawatan neonatus prematur. Namun demikian, penelitian ini baru menyentuh pada aspek proses resusitasi pada neonatus prematur. Oleh karenanya, eksplorasi yang lebih mendalam terhadap makna pengalaman perawat terkait ketidakberhasilan resusitasi pada neonatal asfiksia penting untuk dilakukan. tujuan dari penelitian ini adalah untuk mengeksplorasi makna pengalaman perawat terkait ketidakberhasilan resusitasi pada neonatal dengan asfiksia di ruang neonatus RSUD Dr. R. Soedjono Selong Lombok Timur.

\section{METODE}

Penelitian ini merupakan penelitian kualitatif dengan pendekatan fenomenologi interpretif. Penelitian dilakukan di Ruang neonatus RSUD Dr. R. Soedjono Selong Kabupaten Lombok Timur. Partisipan dalam penelitian ini adalah 7 orang perawat pelaksana yang bekerja di ruang neonatus RSUD Dr. R. Soedjono Selong yang memiliki pengalaman terkait ketidakberhasilan resusitasi pada neonatal dengan asfiksia. Data dikumpulkan melalui wawancara mendalam dengan pertanyaan terbuka dan dikembangkan oleh peneliti. Analisis data dilakukan dengan menggunakan enam tahapan analisa tematik Braun \& Clarke (Braun \& Clarke, 2013). Dalam menyampaikan pernyataan dari partisipan, peneliti menggunakan istilah $\mathrm{p}$ untuk menggantikan partisipan (misalnya p1 untuk partisipan 1 dan seterusnya).

\section{HASIL}

Hasi analisa fenomenologi interpretif terhadap 7 partisipan menghasilkan 8 tema yaitu : memahami kondisi kegawatan pada neonatus yang membutuhkan tindakan resusitasi segera, melakukan resusitasi 
dengan kesadaran akan keterbatasan yang dimiliki, mengalami dilema dengan adanya kehadiran keluarga, merasakan ketidaktentraman hati karena kegagalan resusitasi, berupaya meringankan beban pikiran, mengembalikan semua permasalahan kepada Tuhan, menerima kegagalan sebagai bagian dari pembelajaran, dan menginginkan peningkatan kualitas pelayanan pada kegawatan neonatus.

\section{Tema 1. Memahami Kondisi Kegawatan Pada} Neonatus Yang Membutuhkan Tindakan

\section{Resusitasi Segera}

Tema ini dibangun dari sebuah sub tema yaitu mengenali tanda asfiksia pada neonatus. Memahami kondisi kegawatan pada neonatus yang membutuhkan tindakan resusitasi segera adalah perawat mengetahui dengan benar keadaan kritis pada neonatus dengan asfiksia yang membutuhkan tindakan penyelamatan segera.

\section{Mengenali tanda asfiksia pada neonatus} dibangun oleh dua buah kategori yaitu mengenali kesulitan bernafas dan mengidentifikasi denyut nadi. Pernyataan partisipan terkait mengenali tanda asfiksia pada neonatus tergambar dalam kutipan berikut :

"resusitasi itu kan kalau bayinya tidak bernafas dan menangis secara $\operatorname{spontan}(P 4)^{\prime \prime}$ “...tidak bisa nafas secara spontan dan teratur segera setelah lahir.. jantung kurang dari itu, dari 80."(p5)

“...tidak ada denyut jantungnya sudah tidak mampu berkompensasi..."(p5)

"...keadannya sudah gawat, memang sudah sianosis berat, nafasnya satu, dua..."(p6)

Makna dari pernyataan partisipan diatas adalah perawat mampu memahami tanda kegawatan pada neonatus asfiksia yang membutuhkan tindakan resusitasi dengan melihat dari pernafasan dan denyut jantung.

\section{Tema 2. Melakukan Resusitasi Dengan} Kesadaran Akan Keterbatasan Yang Dimiliki

Melakukan resusitasi dengan kesadaran akan keterbatasan yang dimiliki adalah upaya yang dilakukan perawat dalam memberikan pertolongan pada neonatal dengan asfiksia guna mengurangi morbiditas dan mortalitas pada neonatus dengan asfiksia walaupun perawat sadar akan keterbatasan kompetensi dan peralatan yang dimiliki.

\section{Sub tema 1. Mempersiapkan peralatan} resusitasi sesuai kebutuhan. Mempersiapkan memiliki arti mengatur segala sesuatu dalam hal ini adalah mengatur agar kebutuhan alat resusitasi dapat disiapkan dalam keadaan berfungsi dan lengkap agar resusitasi dapat berjalan dengan lancar. Gambaran hal 
tersebut dapat dilihat dari kutipan partisipan dibawah ini :

“...kita harus sudah mempersiapkan alatalat untuk resusitasinya seperti ambu bag, obat-obatan, oksigen, suction..."(p4L “...resusitasinya meja resusitasi, lengkap sih kayaknya mbak, ambu bag, oksigen, suction sama obat-obatan kecuali pemasangan endo trachel tube ( ETT), biasanya dokter anastesinya yang ngerjain..."

Makna dari pernyataan partisipan diatas menunjukan bahwa kelengkapan alat resusitasi dipersiapkan pada saat melakukan resusitasi neonatal adalah berupa perlengkapan untuk pemberian bantuan pernafasan dan obat-obatan bila diperlukan kecuali ETT merupakan tindakan invasif yang hanya boleh dilakukan oleh tenaga yang terlatih dan kompeten.

\section{Sub tema 2. Melakukan tindakan resusitasi} dengan segenap daya.

Melakukan tindakan resusitasi dengan segenap daya adalah suatu upaya yang dilakukan untuk menghidupkan kembali atau untuk mengembalikan sirkulasi ke organorgan vital untuk mencegah atau mengurangi kerusakan fungsi organ-organ vital terutama jantung dan otak dengan segala kemampuan yang dimiliki. Beberapa pernyataan partisipan berkaitan dengan hal tersebut seperti berikut ini :

"...pertahankan $A B C$, airway, breathing, sirkulasinya Pertama jalan nafas, kita patenkan jalan nafasnya, kalau memang ada lendir kita suction, atur posisinya, kita oksigenkan kemudian kalau memang dia, apa namanya... masih bagus denyut jantungnya kita cukup dengan VTP saja tapi seandainya dia denyut jantungnya sudah tidak bagus dibawah 80 kali maka kita lakukan VTP dan RJP..."(p5)

Makna pernyataan partisipan diatas adalah mereka melakukan resusitasi pada neonatal sesuai kebutuhan dari neonatus. apabila neonatus dapat bernafas spontan hanya dengan melakukan pengeringan dan penghangatan dan stimulasi maka tindakan lain seperti pemberian ventilasi tekanan positif (VTP) dan resusitasi jantung paru (RJP) tidak perlu dilakukan lagi.

\section{Sub tema 3. Melakukan tindakan resusitasi} ditengah keterbatasan.

Melakukan tindakan ditengah keterbatasan memiliki arti upaya yang dilakukan perawat memiliki beberapa kekurangan berupa keterbatasan kompetensi dan fasilitas resusitasi yang tidak memadai namun perawat berusaha memberikan tindakan yang maksimal. Beberapa pernyataan partisipan 
berkaitan dengan hal tersebut seperti berikut ini :

"...ada saat kita melakukan resusitasi, apa namanya, masuknya, masuknya ke paru-paru itu nggak masuk, kadangkadang masuknya ke perut biasanya...prosesnya itu lama kadangkadang kita melakukan resusitasi baru masuk gitu.. .kalau skill, sejauh ini masih kurang kayaknya, khususnya resusitasi... kalau pengetahuan juga ya, apa ya, kita kurang up date mungkin, kalau kita nggak browsing atau segala macam tidak akan tahu..."(p3)

Dari petikan pernyataan partisipan diatas dapat disimpulkan bahwa perawat mempunyai keterbatasan berupa pengetahuan dan keterampilan yang juga kurang, sehingga terkadang mengalami kesulitan saat memberikan tindakan resusitasi pada neonatus dan hasilnya tidak sesuai dengan harapan.

Fasilitas yang kurang memadai merupakan kategori berikut dari melakukan tindakan resusitasi ditengah keterbatasan. Beberapa pernyataan partisipan berkaitan dengan hal tersebut seperti dibawah ini :

"...Alatnya pas-pasan atau kurang lengkap... ambu ambu bag cuma 1, suction 1, trus oksigen 1, bayi asfiksia nanti kadang 2, apalagi kalau sudah gemelli mbak bingung kita, makanya giliran dah yang mana duluan keluar yang itu yang didahulukan, itu tempat susahnya...",(p2)

Dari petikan pernyataan partisipan diatas dapat disimpulkan bahwa alat-alat resusitasi yang mereka gunakan masih belum memadai baik dari segi kuantitas maupun kualitas.

\section{Tema 3. Mengalami Dilema Dengan adanya}

\section{Kehadiran Keluarga Saat Resusitasi}

Tema ini mengandung pertentangan yang dialami oleh perawat ketika memberikan tindakan resusitasi pada neonatus dengan asfiksia yang mempersempit ruang gerak mereka saat memberikan bantuan resusitasi sehingga tidak dapat memberikan pertolongan dengan maksimal.

Keluarga tidak kooperatif, berusaha melakukan suatu penolakan atas tindakan yang dilakukan, dimana keluarga bersikeras untuk menghentikan proses resusitasi yang sedang dilakukan oleh perawat terhadap anaknya. Kutipan dari pernyataan partisipan tersebut dapat dilihat dibawah ini :

“...ibunya yang melarang kita melakukan tindakan resusitasi itu, tapi kita jelaskan kalau tidak dilakukan tindakan ini, kemungkinan bayi ibu akan meninggal, tapi kalau ibunya ngotot tidak mau dilakukan tindakan resusitasi... sedangkan kita sangat berharap untuk 
terus melakukan tindakan resusitasi karena siapa tahu berhasil, tidak ada tindakan yang sia-sia, terus... gimana kalau gitu itu..",(p3)

Makna dari pernyataan partisipan diatas adalah kebingungan mereka mengambil keputusan melanjutkan atau menghentikan tindakan resusitasi karena keluarga mengendaki untuk menghentikan proses resusitasi.

Kategori kedua dari merasakan tidak nyaman dengan kehadiran keluarga adalah ketidakstabilan emosi keluarga yang memiliki arti, luapan emosi dari keluarga yang hadir menyaksikan tindakan resusitasi yang mempengaruhi perawat saat sedang melakukan resusitasi. Kutipan dari pernyataan partisipan tersebut dapat tergambar dibawah ini :

“...lebih nyaman sendiri ya, soalnya kalau ada keluargannya yang suka ngerecokin, malah kita yang nggak fokus, kadangkadang kan kalau keluarga pasien atau ibunya terutama lihat anaknya seperti itu malah yang histeris, malah yang mengganggu kita, konsentrasi kita yang lagi melakukan resusitasi pasiennya gitu malah mungkin kalau dia nggak kuat malah pingsan, nangis, banyak yang sering seperti itu...", (p7)

Makna dari pernyataan partisipan diatas menunjukkan adanya dilema akan kehadiran keluarga didekat mereka saat melakukan tindakan resusitasi pada neonates karena kehadiran mereka mengganggu konsentrasi perawat.

\section{Tema 4 : Merasakan Ketidaktentraman Hati Karena Kegagalan Resusitasi}

Merasakan ketidaktentraman hati karena kegagalan resusitasi adalah merasakan tidak tenang di dalam hati karena ketidakberhasilan upaya penyelamatan pada neonatal dengan asfiksia.

\section{Sub tema 1. Merasakan ketakutan akan} ketidakberhasilan hasil tindakan merupakan perasaan ketakutaan perawat akan hasil resusitasi yang dilakukam saat tindakan resusitasi karena ketakutan akan kegagalan dari tindakan yang dilakukannya.

Pernyataan dari partisipan yang berkaitan dengan Merasakan ketakutan akan ketidakberhasilan hasil tindakan dapat dilihat pada pernyataan dibawah ini :

“...saat melakukan resusitasi, takut iya, panik iya, ya nerves iya gemetaran iya, pertama kali karena takut gagal, karena bila ada apa apa terhadap bayi yang bertanggung jawab kan saya...bayi soalnya keadaannya nggak dia tetap mbak sekarang cepet berubah, kadang sekarang dia nangis keras tiba tiba 5 menit kemudian dia udah merintih, tangisnya udah ngak ada. Itu tempatnya 
saya takutnya mbak sampai sekarang sih... makanya ya sampai sekarang waktu ikut SC masih tetap perasaan takut gagal..",(p2)

Pernyataan partisipan diatas yang mengungkapkan perasaan takut yang memiliki arti yaitu perasaan gentar akan menghadapi sesuatu yang mendatangkan bencana sehingga setiap melakukan resusitasi selalu merasa panik, tegang, dan gemetar karena takut bila tindakannya tersebut akan berujung pada kegagalan karena saat itu neonatus dalam tanggung jawabnya.

\section{Sub tema 2. Merasakan kesedihan yang}

mendalam. Respon emosional yang dirasakan perawat pada saat mengalami kegagalan dalam resusitasi adalah merasakan sedih yang mendalam. Perawat mencurahkan perasaannya dalam berbagai bentuk yaitu merasa sedih, merasa gagal, merasa kasihan, dan perasaan yang bergejolak karena kegagalan. Kutipan pernyataan partisipan tersebut seperti dibawah ini :

"...sedih sih...pas jelasin kekeluarganya itu yang memang susah, tidak bisa diungkapkan dengan kata-kata.. bagaimana ya...", (p2)

"...saya mikirnya kalau saya diposisi ibu ini bagaimana ya perasaannya, saya mikirnya ya Allah sedih sekali saya rasanya.."(p3)
Makna dari pernyataan partisipan diatas adalah perasaan sedih yang dirasakan oleh perawat yang timbul karena bermacammacam alasan, ada yang merasa kasihan karena usaha resusitasi yang mereka lakukan tidak berhasil, dan perasaan bingung bagaimana menyampaikan berita tersebut kepada keluarga.

Kecewa adalah bentuk ekspresi emosional lain yang dirasakan oleh partisipan. Kecewa merupakan perasaan kecil hati dengan apa yang terjadi pada saat ini. Kecewa dirasakan oleh partisipan karena pasien tidak berhasil diselamatkan.

Merasa gagal adalah respon emosional yang juga dirasakan oleh partisipan saat mengalami ketidakberhasilan resusitasi pada neonatal dengan asfiksia. Hal ini terlihat dari pernyataan partisipan dibawah ini :

“..уa sedih....sedih.. terus ya merasa gagal..."(p2)

"...apa ya...merasa ini juga merasa gagal

sekali...gagal sekali rasanya..."(p3)

Pernyataan partisipan diatas menunjukkan perasaan emosional mereka karena tidak berhasil melakukan tindakan penyelamatan nyawa pada neonatus yang ditolongnya.

Merasa bersalah merupakan kategori berikutnya dari dari perasaan sedih yang mendalam. adalah perasaan bersalah yang 
memiliki arti perasaan yang timbul dan terjadi disebabkan oleh apa yang mereka lakukan. Pernyataan partisipan mengenai perasaan bersalah tergambar dari kutipan dibawah ini :

"...tetap saja ada perasaan bersalah, istilahnya bergejolaklah gitu..."(p3)

\section{“...kadang suka menyalahkan diri sendiri}

kenapa tidak berhasil kayak begitu...

kalau tidak berhasil suka merasa

bersalah, kenapa sih saya begitu..."(p6)

Pernyataan partisipan diatas memiliki makna perasaan bersalah muncul karena merasa menghilangkan nyawa neonatus begitu saja.

Sedangkan perasaan empati memiliki arti keadaan mental yang membuat orang merasa atau mengidentifikasi dirinya dalam keadaan perasaan atau fikiran yang sama dengan orang lain. Beberapa pernyataan yang diungkapkan oleh partisipan berkaitan dengan hal tersebut adalah :

"...kalau perasaan, dibilang perasaan empati itu, mungkin pada ibunya..."(p3)

"...kalau kita jaga malam, hampir-hampir kita tidak tidur nungguin dia, padahal batas melakukan resusitasi itu kan ada...nggak kita lelah-lelah karena melihat orang tuanya..."(p4)

Pernyataaan partisipan diatas menunjukkan perasaan empati yang tertuju pada ibunya karena secara psikologis ibu adalah orang yang terdekat yang paling merasakan kehilangan atas kematian bayinya. Rasa empati juga ditunjukkan oleh perawat dengan berusaha sekuat tenaga dan tidak merasa lelah melakukan resusitasi karena merasakan perasaan yang dirasakan oleh keluarga.

\section{Tema 5. Berupaya Meringankan Beban Pikiran}

Berupaya meringankan beban pikiran adalah usaha yang dilakukan untuk mencari jalan keluar dari sesuatu hal yang berat dengan menggunakan akal dan pertimbangan yang baik dan bijaksana. Ketidakberhasilan upaya resusitasi yang menyebabkan kematian pada neonatus dan terjadi secara berulang dapat mengancam dan mempengaruhi pemikiran serta memicu stressor bagi perawat. Sebagai seorang individu, diperlukan suatu strategi koping yaitu strategi dalam menyelesaikan masalah yang mereka hadapi, mengatasi perubahan yang terjadi, dan situasi yang mengancam, baik secara kognitif maupun prilaku.

\section{Sub tema 1. Membagi perasaan dengan}

orang lain. Membagi perasan dengan orang lain merupakan strategi koping yang digunakan oleh beberapa partisipan untuk mengurangi beban yang mereka rasakan akibat kegagalan melakukan resusitasi pada neonatal dengan asfiksia. Berbagi cerita dengan teman sejawat, atasan dan keluarga merupakan salah satu strategi koping yang diungkapkan oleh empat partisipan berikut : 
"... itu dah berbagi ke teman saja atau nggak ke teman shift kalau tidak berhasil.."(p4)

“..jadi saya kalau pulang itu cerita apa saja yang terjadi di kantor, dia juga begitu. Jadi ya, suami saja tempatnya bercerita..."(p5)

Pernyataan diatas menjelaskan bahwa empat orang partisipan tersebut berusaha untuk bercerita kepada teman maupun keluarga untuk mengurangi beban yang mereka rasakan akibat tidak berhasil melakukan resusitasi pada neonatus.

\section{Sub tema 2. Memendam perasaan sendiri.}

Memendam perasaan sendiri merupakan strategi koping yang digunakan oleh tiga orang partisipan, memendam memiliki arti menyembunyikan, menyimpan perasaan atau rahasia yang dimiliki untuk diri sendiri. Hal ini dapat terlihat dari pernyataan partisipan dibawah ini :

“...memang jarang cerita, lebih senang, lebih sering saya pendam sendiri saja sih mbak, mau masalah apa-apa juga jarang saya cerita sama orang...tapi memang saya merasa lebih nyaman, sudah saya sendiri gitu...sudah karakter mungkin...", (p2)

"..ndak pernah dibagi sih, kalau perasaan yang tidak berhasil itu, palingan cuma buat sendiri aja, dan itu aja, ndak dibagi aja...", (p6)

Makna dari pernyataan partisipan diatas adalah partisipan merasa nyaman dengan strategi koping yang digunakan.

Tema 6. Mengembalikan Semua

\section{Permasalahan Kepada Tuhan}

Mengembalikan semua permasalahan kepada Tuhan memiliki arti mengembalikan persoalan atau segala sesuatu yang menyangkut hidup dan mati manusia kepada kekuasaan tertinggi yaitu Sang Maha Pencipta.

\section{Menerima realita akan kegagalan resusitasi,} merupakan pernyataan partisipan terkait kesediaan perawat menerima kenyataan ketidakberhasilan upaya resusitasi yang dilakukan pada neonatus. Perasaan tersebut dirasakan oleh partisipan karena keikhlasan untuk menerima sesuatu yang sudah terjadi. Pernyataan partisipan yang berkaitan dengan hal tersebut diatas adalah :

“..cukup sampai disitu saja mbak, bila kita melakukan suatu tindakan itu terus tidak berhasil, ya pada saat itu kita apa namanya, mengakhirilah karena segala sesuatu itu yang menentukan kan Allah, kan kalau berlebihan itu juga kan nggak baik..."(p1) “...ya kita kembalikan ke atas lah, kita sudah berusaha maksimal ternyata tidak 
berhasil, kita juga harus berusaha tenang..."

Makna dari pernyataan partisipan diatasi menunjukkan bahwa mereka sudah berusaha secara maksimal sesuai kemampuan yang mereka miliki namun Allah adalah penentu segalanya.

\section{Tema 7. Menerima Kegagalan Sebagai Bagian dari Pembelajaran}

Menerima kenyataan kegagalan sebagai sebuah pembelajaran adalah perawat mengambil manfaat dari ketidak berhasilan upaya resusitasi dan berusaha mengambil pelajaran dari kejadian tersebut.

\section{Sub tema 1. Mampu bertahan menghadapi}

kegagalan berulang. Sub tema mampu bertahan menghadapi kegagalan resusitasi berulang memiliki arti perawat dapat beradaptasi atau mampu menghadapi kegagalan tindakan resusitasi pada neonatal asfiksia yang terjadi berulang. Suatu kejadian ketidakberhasilan resusitasi pada neonatus yang sama berulang-ulang terjadi atau dirasakan pada seseorang dalam jangka waktu yang lama menyebabkan orang tersebut merasa bahwa hal tersebut adalah hal yang dapat mereka hadapi. Pernyataan partisipan yang berkaitan dengan hal tersebut diatas adalah : “...mungkin sudah terbiasa lihat bayi yang meninggal, sudah, sudah itu saja gitu, karena sudah terbiasa sekian banyak bayi yang meninggal gagal resusitasi, sekian banyaknya, jadi sudah hal yang lumrah..." (p3)

"...Sudah kebal, udah kebal, jadinya saya kayak punya apa namanya mbak, yang kayak yang ee.ini pasien yang seperti pastinya akan tetap saya temui, baik itu, entah itu 2, 3 hari lagi, karena saya pasti akan tetap kerja disini, itu saya pikir kayak sudah punya mind set sendiri, sudah terbentuk jadinya kalau memang jadi tenaga kesehatan ya memang harus kuat mental..."(p7)

Makna dari pernyataan partisipan diatas adalah kematian pada neonatus cukup banyak dan sering mereka alami membuat mereka dapat beradaptasi dengan kondisi tersebut, maka seiring waktu perasaan tersebut sudah menjadi hal yang biasa dan harus mereka hadapi karena sudah menjadi bagian dari tugas mereka sebagai tenaga kesehatan.

\section{Sub tema 2. Belajar dari ketidakberhasilan.}

Dari suatu kegagalan yang terjadi seseorang bisa mengambil makna pelajaran dari sebuah kegagaPernyatan partisipan yang berkaitan dengan hal tersebut dapat dilihat pada kutipan berikut : 
“...jadi lebih ke memperhatikan ,..yah jadi pelajaran buat saya lah..." (p2)

“...yang jelas apa ya.. pastinya akan berusaha untuk lebih baik lagi kedepan, kerja hati-hati dan selalu mengikuti protap....",(p5)

Makna dari pernyataan partisipan diatas adalah bagaimana perawat akhirnya dapat memandang ketidakberhasilan resusitasi pada neonatal dapat dijadikan motivasi untuk lebih baik lagi kedepan.

Tema 8. Menginginkan Peningkatan Kualitas pelayanan Pada Kondisi kegawatan Neonatus

Tema menginginkan peningkatan kualitas pelayanan pada kondisi kegawatan neonatus adalah harapan perawat agar institusi rumah sakit sebagai pemberi layanan, dapat berproses ke arah yang lebih baik dalam rangka meningkatkan mutu layanan resusitasi pada neonatal dengan asfiksia guna mengurangi frekwensi ketidakberhasilan dimasa yang akan datang.

\section{Sub tema 1. Menginginkan peningkatan}

pengetahuan dan keterampilan. Peningkatan kemampuan pengetahuan dan keterampilan perawat diperlukan untuk memberikan pemahaman dan keterampilan perawat terkait lingkup kerjanya. Peningkatan kualitas sumber daya manusia ini dapat dilakukan dengan beberapa cara antara lain dengan pelatihan, penyegaran yang dilakukan secara berkala dan pengarahan ketika terjadi ketidakberhasilan. Pernyataan partisipan yang berkaitan dengan dua hal tersebut dapat dilihat dari kutipan wawancara di bawah ini : "...ya menurut saya kurang sekali penyegaran...perasaan sudah berapa tahun yang lalu penyegaran...kalau memang mencukupi dananya, ee kita paling tidak karena kita yang menangani langsung kita yang disuruh gantian pelatihan..."(p4)

"...mungkin dari rumah sakit mengadakan pelatihan sendiri untuk resusitasi neonatal..."(p6)

Dari pernyataan kelima partisipan diatas menunjukan bahwa, adanya keinginan yang besar dari partisipan agar rumah sakit dapat mengirim mereka untuk mengikuti pelatihan resusitasi neonatal secara bergilir atau mengadakan pelatihan dan penyegaran internal rumah sakit secara berkala untuk meningkatkan pengetahuan dan keterampilan mereka dan agar dapat menyesuaikan diri dengan perkembangan ilmu pengetahuan yang diharapkan berdampak pada menurunnya kasus kematian neonatal.

Partisipan juga menyebutkan kategori lain untuk meningkatkan kemampuan sumber daya manusia yaitu, perlunya brifing atau pengarahan yang merupakan kategori terakhir dari peningkatan kemampuan sumber daya 
manusia. Pernyataan partisipan yang berkaitan dengan hal tersebut dapat dilihat dari kutipan wawancara di bawah ini :

“...harusnya diadakan rutin pengarahan supaya kita lebih tenang, ada dukungan..."(p2)

"...harusnya sih perlu mbak yang brifing...misalnya tidak berhasil, harusnya kita analisa mengapa tidak berhasil..."(p5)

Makna dari pernyataan tersebut adalah pengarahan setelah proses ketidakberhasilan resusitasi perlu dilakukan sebagai sarana introspeksi diri dan koreksi agar kedepan hal tersebut tidak terulang kembali.

\section{Sub tema 2. Menginginkan dukungan} peralatan resusitasi yang memadai. Fasilitas merupakan hal pokok yang harus disediakan oleh sebuah institusi untuk menunjang kegiatan dalam institusi tersebut. Fasilitas yang disedikan di ruang neonatus adalah fasilitas yang digunakan untuk menunjang penatalaksanaan pasien di ruang neonatus, termasuk peralatan untuk resusitasi. Pernyataan partisipan yang berkaitan dengan hal tersebut dapat dilihat dari kutipan di bawah ini :

"...suctionnya kadang kurang, kita gantian makai karena ada pasien lain juga makai, karena nggak 1 pasien kan yang diresusitasi, jadinya kan giliran..."(p2) "...kemudian rumah sakit sendiri, kayaknya perlu dah menyiapkan CPAP... agar dapat maksimal pemberian oksigenasinya..."(p5)

Makna dari pernyataan partisipan tersebut adalah adanya harapan agar disediakan peralatan yang ideal sehingga mereka dapat melakukan upaya resusitasi dan tindakan terkait pertolongan pada kegawatan neonatus dengan optimal.

\section{PEMBAHASAN}

Pemahaman adalah kemampuan seseorang untuk mengerti atau memahami sesuatu setelah sesuatu itu diketahui dan diingat (Notoadmodjo, 2012). Dengan kata lain, memahami adalah mengetahui tentang sesuatu dan dapat melihatnya dari berbagai segi. Seorang dikatakan memahami sesuatu apabila ia dapat memberikan penjelasan atau memberi uraian yang lebih rinci tentang hal itu dengan menggunakan kata-katanya sendiri (Notoadmodjo, 2012).

Pemahaman merupakan jenjang kemampuan berpikir yang setingkat lebih tinggi dari ingatan atau hafalan. Perawat ruang neonatus sebagai orang pertama yang menemukan kondisi kegawatan pada neonatus dengan asfiksia, mampu memahami kondisi yang membutuhkan tindakan resusitasi segera pada neonatal dengan asfiksia. Kegawatan neonatal adalah situasi yang membutuhkan 
evaluasi dan manajemen yang tepat pada bayi baru lahir yang kritis dan membutuhkan pengetahuan yang dalam mengenali perubahan psikologis dan kondisi patologis yang mengancam jiwa yang bisa saja timbul sewaktu-waktu(Brousseau \& Sharieff, 2006).

Sebagai seorang perawat yang memiliki kewajiban untuk mengambil keputusan pemberian resusitasi secara maksimal kepada neonatus yang membutuhkan tindakan resusitasi, perawat berusaha untuk menyiapkan segala keperluan tindakan berjalan denga baik dan lancar. Penerapan langkah-langkah resusitasi dilakukan dengan harapan tindakan tersebut dapat membantu menyelamatkan neonatus ataupun mengurangi dampak kerusakan organ vital yang lebih lanjut. Namun dalam upaya tersebut terkendala dengan kurangnya kompetensi dan peralatan resusitasi yang kurang memadai serta dilema yang timbul akibat kehadiran keluarga saat resusitasi. Faktor kemampuan perawat sangat mempengaruhi angka kematian atau angka survival rate dari pasien. Salah satu kemampuan yang sangat penting yang harus dikuasai oleh perawat adalah kemampuan dalam melakukan Cardio Pulmonary Resuscitation (Dwyer \& Williams, 2002).

Hambatan yang dialami dan dirasakan saat memberikan upaya resusitasi pada neonatal dengan asfiksia dapat berasal dari keluarga pasien. Kehadiran keluarga di ruangan pada saat resusitasi merupakan suatu dilema bagi perawat, karena keluarga terkadang tidak menyetujui tindakan resusitasi dan sering mengeluarkan komentar-komentar tertentu, histeris, menangis dan pingsan yang membuat perawat tidak fokus melakukan tindakan resusitasi.

Kehadiran keluarga dalam proses resusitasi sejak dahulu selalu menjadi kontroversi dan menimbulkan berbagai pendapat baik itu yang bersifat mendukung maupun menolak. Ritme kerja yang cepat dan tekanan yang tinggi dalam proses resusitasi menyebabkan terbatasnya sikap empati, komunikasi dan keterlibatan petugas kesehatan dengan pasien dan keluarga (Steiger \& Balog, 2010) . Selain itu kerugian dengan adanya kebijakan menghadirkan keluarga selama proses resusitasi diantranya menyebabkan trauma psikologis, dan keluarga dapat mengganggu selama berjalannya prosedur resusitasi (Demir, 2008).

Respon psikologis yang dimunculkan oleh perawat menghadapi ketidakberhasilan resusitasi berupa perasaan takut tindakan resusitasi yang diberikan. Perubahan kondisi neonatus yang tidak dapat diprediksi dalam proses resusitasi, ketakutan akan dampak tindakan yang dilakukan terhadap neonatus 
akan memperparah kondisi dari neonatus dan rasa tanggung jawab terhadap kondisi pasien merupakan alasan munculnya perasaan ini.

Dalam studi penelitian fenomenologi mereka, Isaacs Paterson mewawancarai perawat ICU untuk mengetahui pengalaman hidup mereka yang mengalami kegagalan dalam melakukan resusitasi. Dengan menggunakan kerangka kerja Colaizzi untuk analisis, dua kategori muncul dari kelompok tema, yaitu tahu apa yang diharapkan dan akibatnya. Mengetahui apa yang diharapkan selama resusitasi, prosedur dan hasil dari upaya mereka dianggap penting oleh partisipan dalam upaya mengetahui kemampuan mereka untuk mengatasi emosi terkait dengan ketidakberhasilan resusitasi (Isaacs \& Mash, 2004).

Ketidakberhasilan dalam upaya resusitasi pada neonatal dengan asfiksia sering dialami oleh partisipan, saat pertama kali mengalami keadaan tersebut mereka merasakan kesedihan yang mendalam. Namun seiring dengan waktu dan oleh karena kematian pada neonatal sering mereka alami secara berulang-ulang membuat mereka tidak lagi merasakan perasaan yang terlalu mendalam. Hasil penelitian yang dilakukan oleh Enggune menyatakan bahwa perawat merasakan perasaan yang biasa saja menghadapi kondisi menjelang ajal dan kematian karena sering menghadapi hal tersebut yang mengakibatkan terbentuk persepsi dan adaptasi terhadap dampak menghadapi kondisi menjelang ajal dan kematian (Enggune, Ibrahim, \& Agustina, 2014).

Makna yang dapat diambil oleh partisipan setelah mengalami ketidakberhasilan resusitasi neonatal yang berulang adalah mereka merasa lebih tenang, lebih enjoy, berusaha melakukan tindakan keperawatan dengan benar, dan lebih perhatian. Kegagalan dalam melakukan resusitasi pada neonatal menurut beberapa partisipan akan mereka temukan entah hari ini esok hari ataupun dihari-hari berikutnya selama mereka bekerja pada kondisi yang mengharuskan mereka bersentuhan dengan pasien, maka kegagalan akan selalu beriringan dengan keberhasilan. Kegagalan berulang membuat mereka termotivasi untuk bekerja lebih baik dan lebih optimal agar dapat mengurangi kejadian tersebut di masa yang akan datang.

Strategi pertama yang digunakan oleh sebagian perawat untuk mengurangi stressor emosional yang dialami ketika tidak berhasil melakukan resusitasi pada neonatus dengan asfiksia adalah menggunakan strategi koping yang berpusat pada masalah (problem focused coping) mereka berusaha membagi perasaan mereka dengan teman, atasan maupun keluarga. Sebagian perawat memilih 
menggunakan strategi koping yang berfokus pada emosional (emotional focused coping) dengan tidak membagi hal-hal mengenai ketidakberhasilan resusitasi neonatal karena merasa lebih nyaman memendam perasaan itu sendiri.

Berdasarkan hasil penelitian yang dilakukan Haryini terhadap 34 orang perawat di instalasi gawat darurat, diketahui bahwa sebagian besar responden (67,6\%) menggunakan emotional focused coping dan sisanya $(32,4 \%)$ menggunakan problem focused coping (Haryuni, 2013). Hasil penelitian tersebut sesuai dengan penelitian yang dilakukan Gholamzadeh, dimana sebagian besar perawat di Iran menggunakan emotional focused coping (Gholamzadeh, Syarif, \& Rad, 2011).

Kemampuan perawat merupakan hal yang sangat menetukan kualitas pelaksanaan resusitasi pada neonatal dengan asfiksia. Kemampuan tersebut dapat ditingkatkan melalui pelatihan, khususnya pelatihan resusitasi neonatal. Pengetahuan dan keterampilan dari anggota tim dapat dibangun melalui pelatihan-pelatihan. Dengan pengetahuan dan keterampilan yang baik maka anggota tim akan dapat melakukan resusitasi yang berkualitas tinggi (Jantti, 2010).

Keterbatasan fasilitas dan tidak berfungsinya peralatan yang menunjang pelaksanaan resusitasi yang menyebabkan perawat kurang maksimal dalam melakukan tindakan resusitasi pada neonatus sesuai dengan standart yang ada. Hal ini sesuai dengan salah satu hasil penelitian Noris \& Lockey yang menyatakan bahwa kurangnya fasilitas dan tidak berfungsinya peralatan resuitasi dengan baik dapat menurunkan kualitas pelaksanaan CPR (Noris \& Lockey, 2012).

\section{KESIMPULAN}

Perawat memiliki kemampuan memahami kondisi kegawatan pada neonatus dengan asfiksia untuk dapat segera memberikan tindakan resusitasi. Perawat memiliki kesulitan tersendiri dalam pelaksanaan proses resusitasi pada neonatus dengan asfiksia, dimana kesulitan tersebut tidak hanya berasal dari kemampuan dan keterampilan perawat sendiri namun merupakan suatu rangkaian yang kompleks.

Dampak psikologis yang dihadapi perawat dalam upaya penyelamatan nyawa pada neonatus dengan asfiksia harus lebih diperhatikan, karena ketidakberhasilan tindakan resusitasi pada neonatal dapat menimbulkan stressor psikologis. Dalam upayanya untuk mengurangi dampak psikologis yang timbul akibat ketidakberhasilan resusitasi pada neonatal dengan asfiksia, perawat menggunakan strategi koping yang konstruktif sehingga 
dapat mengambil hikmah dari sebuah kegagalan. Namun dalam rangka meningkatkan mutu pelayanan pada neonatal secara umum dan pemberian pelayanan tindakan resusitasi pada neonatal asfiksia

\section{DAFTAR PUSTAKA}

ACOG \& AAP (2015) ACOG \& AAP. (2015).

Committee opinion: The APGAR score.

Braun, V. \& Clarke, V. (2013) Teaching thematic analysis: Over-coming challenges and developing strategies for effective learning.The Psychologist, 26(2),120-123.

Brousseau, T., \& Sharieff, G. Q. (2006). Newborn emergencies: the first 30 days of life. Pediatric Clinics of North America, 53(1), 69-84.

Cole, F. L., Slocumb, E. M., \& Mastey, J. M. (2001). A measure of critical care nurses' post-code stress. Journal of Advanced Nursing, 34(3), 281-288.

Demir, F. (2008). Presence of patiens families during cardiopulmonary resuscitation: physician and nurses opinions. Journal of advenced nursing. 63(4):409-416.

Dwyer \& Williams (2002Dwyer, T., \& Williams, L. M. (2002). Nurses' behaviour regarding CPR and the theories of reasoned action secara khusus, dibutuhkan suatu dukungan agar upaya resusitasi dapat dilakukan secara optimal, sehingga berdampak positif pada berkurangnya kejadian ketidakberhasilan resusitasi pada neonatal dengan asfiksia.

and planned behaviour. Resuscitation, 52(1), 85-90.

Enggune, M., Ibrahim, K., \& Agustina, H. R. (2014). Persepsi Perawat Neurosurgical Critical Care Unitterhadap Perawatan Pasien Menjelang Ajal.Jurnal Keperawatan Padjadjaran, 2(1).WHO (2012) WHO Guidelines Approved by the Guidelines Review Committee. (2012). Guidelines on basic newborn resuscitation. Geneva: World Health Organization.

Gholamzadeh S., Syarif H., \& Rad F.D. (2011). Sourse of occupational stress and coping strategies among nurses who are working in admission and emergency departmen in hospital affiliated to Shiraz University of medical science Iran. Iranian Journal of Nursing and midwifery Research. 16: (1): 42-47.

Haryuni. (2013). Hubungan antara stres kerja dan mekanisme koping dengan kinerja perawat di Instalasi Gawat Darurat RSUD Ngudi Waluto Kab. Blitar dan RSD Mardi waluyo kota Blitar. Tesis. 36-51. 
Hemming, T. R., Hudson, M. F., Durham, C., \& Richuso, K. (2003). Effective resuscitation by nurses: perceived barriers and needs. Journal for Nurses in Professional Development, 19(5), 254-259.

Isaacs, I. \& Mash, R.J. (2004) An unsuccessful resuscitation: The families' and doctors' experiences of the unexpected death of a patient, South African Family Practice, $46: 8,20-25$.

Jantti H. (2010). Cardiopulmonary resuscitation quality and education. Disertation in Health Science. University of Eastern Finland.

Karloicz, M., Karotkin, E., Goldsmith, J. (2011). Resuscitation. In E. Karotkin\& J. Goldsmith (Eds.). Assisted Ventilation of the neonate (4 ed.,pp.71-93): Saunders.

Maesyaroh, A. (2015). Pengalaman perawat dalam melaksanakan resusitasi pada kegawatan neonatus prematur di ruang neonatus RSD DR. Haryoto Lumajang. Tesis.

Moleong, L.J.2014. Metode penelitian kualitatif. Edisi Revisi. PT Remaja Rosda Karya Bandung.

Notoadmodjo, S. (2012). Promosi Kesehatan dan Perilaku Kesehatan Taylor, Kemode, Robert, 2007)

Noris, E. M., \& Lockey, A. S. (2012). Human factor in resuscitation teaching. Resuscitation, 83, 422-427

Steiger, N. J., \& Balog, A. (2010). Realizing patient-centered care: putting patients in the center, not the middle. Frontiers of health services management, 26(4), 15.

Taylor, B., Kemode, S., Robert, K. (2007). Research in nursing and health care: Evidence of practice. $3^{\text {rd }}$ Edition. Thomson Nelson Australia Pty Limitid. 